\title{
Induksi Kalus Morfogenik dan Regenerasi Tanaman Tebu (Saccharum officinarum L.) secara In Vitro
}

\author{
Induction of Morphogenic Callus and In Vitro Regeneration of Sugarcane \\ (Saccharum officinarum L.)
}

\author{
Author(s): Sitti Inderiati ${ }^{(1) *} ;$ Yanti $^{(1)} ;$ Eka Ria Mentari $^{(1)}$ \\ (1) Politeknik Pertanian Negeri Pangkep \\ * Corresponding author: sitti.inderiati@gmail.com
}

\begin{abstract}
ABSTRAK
Propagasi in vitro merupakan cara memperoleh tanaman baru yang sehat secara cepat dan Kata Kunci: massal, Percobaan in vitro dilaksanakan untuk menginduksi kalus morfogenik dan regenerasi dari varietas tebu domestik. Bagian terdalam gulungan daun tebu digunakan In vitro; sebagai eksplan dan diinkubasi pada medium MS yang dimodifikasi dan dilengkapi dengan kalus; 2,4-D pada konsentrasi $1 \mathrm{mg} / \mathrm{L}, 2.5 \mathrm{mg} / \mathrm{L}$, dan $5 \mathrm{mg} / \mathrm{L}$ untuk menginduksi pembentukan kalus. Kalus yang terbentuk di medium induksi selanjutnya dipindahkan ke medium MS regenerasi; yang diperkaya dengan zat pengatur tumbuh untuk inisiasi dan perbanyakan tunas. Persentase pembentukan kalus tertinggi dicapai pada penggunaan medium yang mengandung $2.5 \mathrm{mg} / \mathrm{L} \mathrm{2,4-D} \mathrm{dan} \mathrm{maksimal} \mathrm{proliferasi} \mathrm{kalus} \mathrm{morfogenik} \mathrm{diperoleh} \mathrm{setelah}$ subkultur ketiga. Dua tipe kalus yang terbentuk pada medium induksi yaitu berstruktur kering, remah dan struktur halus kompak. Jenis kalus yang morfogenik tersebut berwarna putih dan putih kekuningan serta mudah terpisah-pisah. Hasil proliferasi tunas dari kalus tertinggi diperoleh pada medium MS dengan kombinasi hormon tumbuh $2 \mathrm{mg} / \mathrm{L}$ Kinetin + $1 \mathrm{mg} / \mathrm{L}$ IAA dan tidak ada pertumbuhan tunas pada medium yang ditambahkan zat pengatur tumbuh tunggal, yaitu Kinetin. Dengan demikian, penelitian ini menyimpulkan bahwa hormon tumbuh jenis sitokinin yang dikombinasi dengan auksin sangat dibutuhkan untuk regenerasi kalus tebu secara in vitro.
\end{abstract}

Keywords:

Callus;

In vitro;

Regeneration;

Sugarcane.

\section{ABSTRACT}

In vitro propagation is a method to produce massive healthy new planting materials quickly. An experiment was carried out for morphogenic callus induction and regeneration of a domestic sugarcane variety. The Explants used was an inert folded leaf and incubated on modified MS medium augmented with $1 \mathrm{mg} / \mathrm{L}, 2.5 \mathrm{mg} / \mathrm{L}$, and 5 $m g / L$ of 2,4-D for callus induction. The leaf calluses were subcultured on MS medium enriched with different growth regulators for shoot initiation and multiplication. The highest percentage of callus formation was achieved in the medium containing 2.5 $m g / L$ of 2,4-D, while the fastest callus initiation was noticed in MS medium supplemented with $5 \mathrm{mg} / \mathrm{L}$ 2,4-D, and maximum proliferation and morphogenic respond of callus were obtained in 3rd subculture. Two types of callus observed on the induction medium were dry nodular friable and smooth compact. This highly morphogenic callus was white to white creamy in color and easy to separate. The highest shoot proliferation rate was found on the medium containing $2 \mathrm{mg} / \mathrm{L}$ Kinetin $+1 \mathrm{mg} / \mathrm{L}$ IAA and none growth was noticed on medium containing Kinetin alone. Therefore, the study suggests that the growth hormone of cytokinin in combination with auxin is necessary for in vitro regeneration of sugarcane callus culture. 


\section{INTRODUCTION}

Sugarcane is the main source of the world's sugar production and imperative industrial raw substance for industries producing alcohol, acetic acid, paper, plywood, industrial enzymes (Wardani \& Pertiwi, 2013); de Souza, Grandis, Leite, \& Buckeridge, 2014). It also one of the agricultural cash crops with a high trade value concerning the export product in many developing countries including Indonesia. Consumption of sugarcane is predicted to increase rapidly as the world population increases, consequently, an increase in production is required and improved planting materials are needed to enhance the production.

This economically important crop is mostly propagated through stem cutting. However, this vegetative propagation is slow usually one to ten seedlings in one year, conducive to diseases transmission and the pathogens keep on accumulating generation after generation, which lessens the harvest and quality of sugarcane (Biradar, Biradar, Patil, Patil, \& Kambar, 2010); (Getnet, 2017). Tissue culture derivated sugarcane plants displayed better agronomic characters including a higher number of tillers and segments as compared to the conventional vegetative plant's source (Dewi, Manuhara, Winarsih, \& Purnobasuki, 2017). Therefore, sugarcane seed production through in vitro culture is a suitable and effective method for rapid propagation and production of disease-free planting materials.

Micropropagation protocols of sugarcane have been developed by some researchers through callus culture (Yadav \& Ahmad, 2013); (Alcantara, Dibax, Oliveira, Bespalhok Filho, \& Daros, 2014); (Rao, 2015); (Thirunavukkarasu, Saraniya, \& Ramanathan, 2015); (Jamil et al., 2017) and direct organogenesis using shoot tip explants or apical meristem ((Balagalla, Wijesuriya, Ranathunge, \& Perera, 2017): (Redae \& Ambaye, 2018); (Tesfa \& Ftwi,
2018); (Hailu, Chimdessa, \& Muthswamy, 2018). However, the response of different genotypes of sugarcane in tissue culture is varied. Therefore, this study was conducted to develop an efficient method for regeneration of a cultivated sugarcane variety through callus culture.

\section{METHODOLOGY}

The study was carried out in the Plant tissue culture laboratory of Pangkep State Polytechnic of Agriculture (PSPA). Shoots containing folded leaves of a mature plant of sugarcane (CM 2012 variety) were procured from the experimental field of PSPA and washed thoroughly under running tap water before taking to an aseptic culture room. The spindles (about $20 \mathrm{~cm}$ long) were taken into a laminar airflow cabinet and surfacesterilized by dipping into alcohol $70 \%$ and flaming. The leaf sheaths around the spindle were removed aseptically by the use of a pair of forceps and a scalpel blade.

The segment of tightly rolled internal leaves was excised from the stalk apex and cut into small pieces $(0.5-1 \mathrm{~cm}$ in length) and cultured onto callus induction medium (two explants/bottle culture). The medium Murashige \& Skoog (MS) basal medium was used and augmented with either $1 \mathrm{mg} / \mathrm{L}, 2.5 \mathrm{mg} / \mathrm{L}$ or $5 \mathrm{mg} / \mathrm{L}$ of 2,4-dichlorophenoxyacetic acid (2,4-D), $0.3 \mathrm{~g} / \mathrm{L}$ casein hydrolysate, $35 \mathrm{~g} / \mathrm{L}$ sucrose, and $8 \mathrm{~g} / \mathrm{L}$ Bacto agar was used as the gelling agent. The $\mathrm{pH}$ was adjusted to 5.7 before be autoclaved at $15 \mathrm{psi}\left(121^{\circ} \mathrm{C}\right)$ for 20 minutes. The cultures were stored in an incubated room under the dark condition at $25^{\circ} \mathrm{C}$ and sub-cultured after every 15 days interval until abundant calli were obtained.

The experiment was arranged in a completely randomized design and every treatment of 2,4-dichlorophenoxyacetic acid concentration was replicated ten times. Data were recorded on the frequency of callus formation, time is taken 
to induce callus, callus color, and type of callus compactness and smoothness. The callus induced tissues were transferred to MS medium supplemented with cytokinin $(2.0 \mathrm{mg} / \mathrm{L}$ Kinetin) and a combination of 2 $\mathrm{mg} / \mathrm{L}$ Kinetin and $0.5 \mathrm{mg} / \mathrm{L}$ Indole-3Acetic Acid (IAA) or $2 \mathrm{mg} / \mathrm{L}$ Kinetin and $1 \mathrm{mg} / \mathrm{L}$ IAA for shoot regeneration. All the cultures were maintained at a temperature of $25 \pm 1.0^{\circ} \mathrm{C}$ and the photoperiod was 16 hours with 8 hours dark period in every 24 hour cycle. Subculturing was performed after every 3 weeks interval and plantlet regeneration in different hormonal supplementation was recorded on a daily basis observation for 90 days.

\section{RESULT AND DISCUSSION}

The effect of different concentrations of auxin 2,4-D for callus induction and development was observed in this study. Three weeks after inoculation, callus initiation began with small white clusters of and creamy surfaces. The proliferation of callus was significantly increased with sub-culturing and the maximum growth response was achieved in 3rd subculturing. Among the different concentrations of the hormone used, $5 \mathrm{mg} / \mathrm{L}$ had better influence than 2,4$\mathrm{D}$ at the lower concentration for callus initiation. Although in all induction medium calli were produced, however, more profuse callus induction was observed at $2.5 \mathrm{mg} / \mathrm{L}$ of $2,4-\mathrm{D}$. In this media composition, the percentage of callus induction was $93.33 \%$ (Table 1). A previous experiment by (Thirunavukkarasu et al., 2015) showed a similar result that 2,4-D $2.5 \mathrm{mg} / \mathrm{L}$ produced the highest percentage of callus induction from leaf roll explants in co-91017 variety of sugarcane. It is also shown in Table 1 that the highest concentration of auxin 2,4 D used did not stimulate callus development. The use of 2,4-D for the induction of morphogenic callus in sugarcane has been reported in various studies (Silveira et al., 2013); (Alcantara et al., 2014); (Sholeha, Sugiharto, Setyati, \& Dewanti, 2015); (Rao, 2015); (Kona et al., 2019). These authors reported that 3-4 mg/L 2, 4-D was more potent for callus induction and its subsequent growth. In another study, the maximum amount of callus induction in the sugarcane cultivar was achieved when the young roll leaf explants cultured on MS medium supplemented with 2,4-D $1 \mathrm{mg} / \mathrm{L}$, and the percentage gradually decreased when the concentration of 2,4-D increased from 2.0 to $5.0 \mathrm{mg} / \mathrm{L}$ (Tiwari, Arya, \& Kumar, 2012); (Thirunavukkarasu et al., 2015). All these reports proved that 2,4-D is a proper growth hormone for callus induction in sugarcane, however different varieties of sugarcane showed vary response toward concentration of the hormone used.

Table 1. Effect of Different Concentration 2,4-D on Callus Induction from the Leaf Sheath Explants of Sugarcane Variety CM 2012 after 3-4 weeks of inoculation

\begin{tabular}{clcc}
\hline $\begin{array}{l}\text { Concentration of } \\
2,4 \mathrm{D}(\mathrm{mg} / \mathrm{L})\end{array}$ & $\begin{array}{l}\text { Days for callus } \\
\text { initiation }\end{array}$ & $\begin{array}{l}\text { Number of } \\
\text { explants cultured }\end{array}$ & $\begin{array}{l}\text { \% of explants } \\
\text { formed in callus }\end{array}$ \\
\hline 1 & $14.60 \pm 0.50 \mathrm{a}$ & 15 & 66.66 \\
2.5 & $21.20 \pm 0.20 \mathrm{~b}$ & 15 & 93.33 \\
5 & $11.60 \pm 0.24 \mathrm{c}$ & 15 & 50.33 \\
\hline
\end{tabular}

Means followed by a different letter in each column are significantly different at LSD $(P=0.05)$.

The most abundantly formed callus was dry nodular and friable which was white creamy to brown creamy in color and was highly morphogenic (Figure 1a, 1b, \& 1c). 

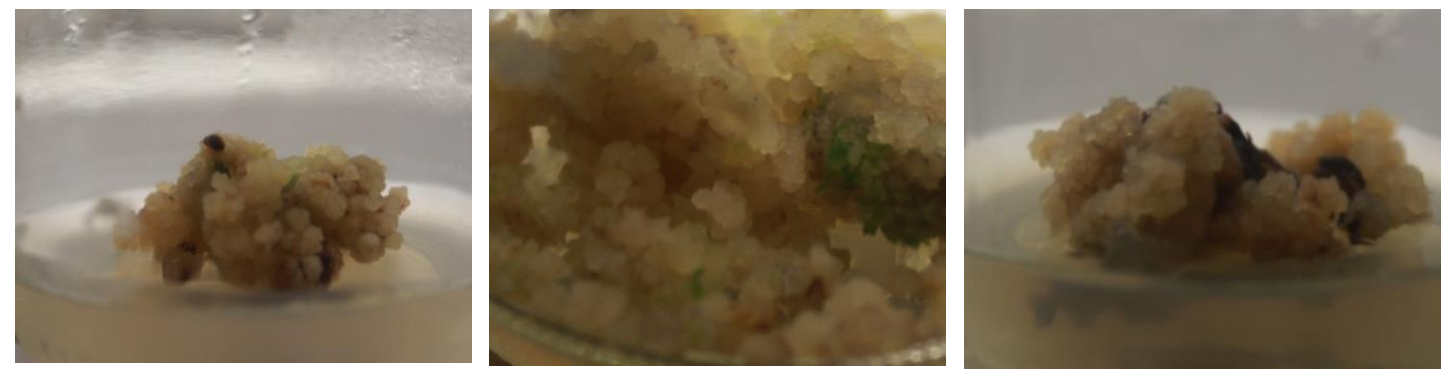

Figure 1. Nodular friable callus develops on MS and formed from leaf explant after 60 days of inoculation in 3rd subculture medium containing $1 \mathrm{mg} / \mathrm{L} \mathrm{2,4-D} \mathrm{(left);} \mathrm{Dry} \mathrm{nodular} \mathrm{friable}$ structure of callus with green patches formed from leaf explant after 60 days of inoculation in 3rd subculture on MS medium containing $2.5 \mathrm{mg} / \mathrm{L} \mathrm{2,4-D} \mathrm{(middle);} \mathrm{Well} \mathrm{developed} \mathrm{dry}$ nodular compact callus formed from leaf sheath explant after 60 days of inoculation in 3rd subculture on MS medium containing $5 \mathrm{mg} / \mathrm{L}$ 2,4-D (right).

Dry nodular and friable callus which was morphogenic has been found by (Sholeha et al., 2015) and (Jamil et al., 2017)in the four sugarcane cultivars (CPF246, CPF-247, CPF-248, and CPF-249). Such type of calli was also confirmed through a histological study in the sugarcane variety SP79-1011 (Silveira et al., 2013) and cultivars RB855156 and RB72454 (Alcantara et al., 2014). The studies revealed that the callus was whitish, nodular-like arrangements, composed of cells with dense cytoplasm and a nucleus with an evident nucleolus, and had a high ratio of nucleus to the cytoplasm, indicating the presence of meristematic zones that lead to the development of shoots. As described by the previous research, the morphology structure of callus is related to their ability to differentiate shoots, hence this present study also confirms the effect of morphology on the regeneration capacity of the induced callus.

After the establishment of callus from leaf sheath, MS medium fortified with Kinetin alone and in combination with IAA were used for shoot induction and proliferation. Small shoots were observed generating from the modular structure (Figure 2a) within three weeks after transfer to the MS medium with a hormonal combination as described in Table 2.
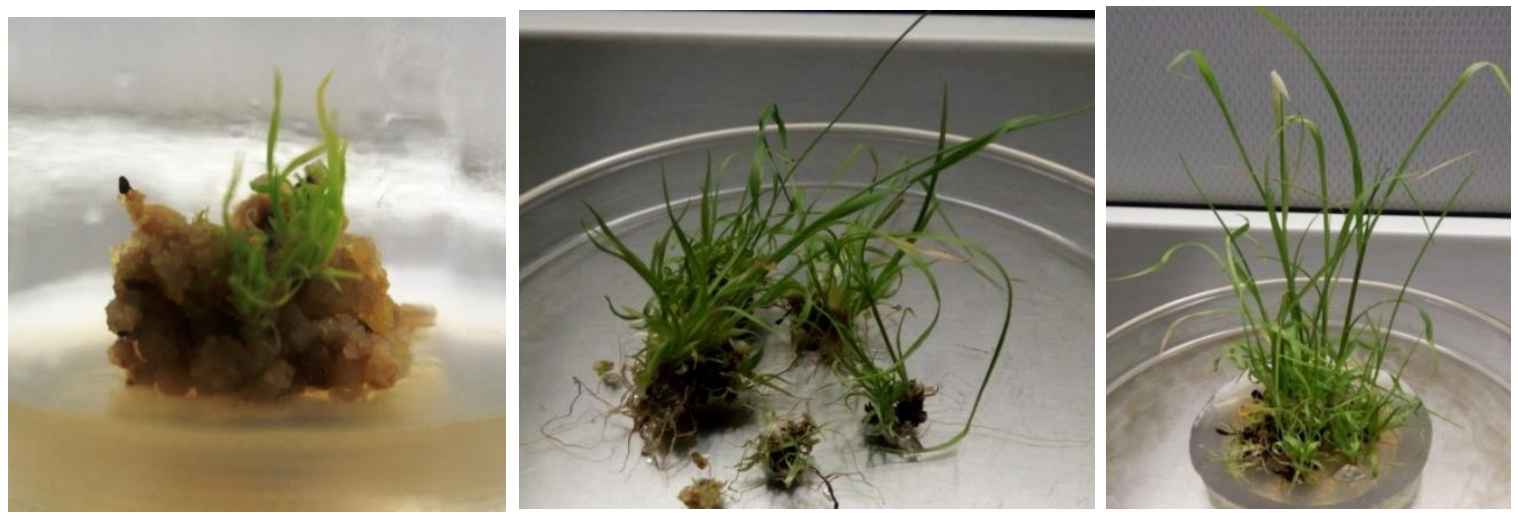

Figure 2. Shoots initiation from callus culture on MS medium suplemented with $2 \mathrm{mg} / \mathrm{L} \mathrm{Kn}$ $+1 \mathrm{mg} / \mathrm{L}$ IAA (left); Plantlets regeneration from callus after 2 months inoculated on MS medium containing $2 \mathrm{mg} / \mathrm{L} \mathrm{Kn}+0.5 \mathrm{mg} / \mathrm{L}$ IAA (middle); 3 months old plants regeneration from callus on MS medium containing $2 \mathrm{mg} / \mathrm{L} \mathrm{Kn}+1 \mathrm{mg} / \mathrm{L} \mathrm{IAA}$ (right).

(cc) BY-SA 
Most calli turned yellow to brown and within 5-6 weeks almost the entire callus surfaces were covered with green and healthy micro shoots. Multiplication of shoots was profuse following the subculture and subsequent growth as indicated by vigorous multi shoots, leaf development, tiny root formation, and height increase of subcultured plantlets was favorable (Figure $2 \mathrm{~b}$ and $2 \mathrm{c}$ ). After subculturing twice, $2 \mathrm{mg} / \mathrm{L} \mathrm{Kin}+1 \mathrm{mg} / \mathrm{L}$ IAA was found to have a better promote effect in the regeneration of shoot from the callus tissue as the number of shoots and the percentage of explants produce shoots on this media composition were significantly higher than $2 \mathrm{mg} / \mathrm{L}$ Kinetin + $0.5 \mathrm{mg} / \mathrm{L}$ IAA (Table 2).

Table 2. Effect of Different Concentration of Kinetin and IAA on Shoot Regeneration from Callus of Sugarcane Variety CM 2012 after 12 Weeks of Inoculation

\begin{tabular}{lccc}
\hline Growth Hormone & $\begin{array}{c}\text { Days for shoots } \\
\text { initiation }( \pm \mathrm{SE})\end{array}$ & $\begin{array}{c}\text { \% of explants } \\
\text { produced shoots }\end{array}$ & $\begin{array}{c}\text { No. of shoots per } \\
\text { explant }( \pm \mathrm{SE})\end{array}$ \\
\hline $\begin{array}{l}\text { Kinetin } 2 \mathrm{mg} / \mathrm{L} \\
\text { Kinetin } 2 \mathrm{mg} / \mathrm{L}+\text { IAA } 0.5\end{array}$ & $\begin{array}{c}18.80 \pm 0.49 \mathrm{a} \\
\mathrm{mg} / \mathrm{L}\end{array}$ & $\begin{array}{c}73.33 \\
0.00 \mathrm{c}\end{array}$ \\
Kinetin $2 \mathrm{mg} / \mathrm{L}+$ IAA $1 \mathrm{mg} / \mathrm{L}$ & $20.20 \pm 0.21 \mathrm{a}$ & 86.66 & $15.78 \pm 0.19 \mathrm{~b}$ \\
& & & $19.82 \pm 0.16 \mathrm{a}$
\end{tabular}

Values are mean of five replicates, mean following by common letters are not significantly different at LSD $(P<0.05)$.

Data presented in Table 2 confirmed that the single hormone has no effect for shoot induction from the callus of the sugarcane cultivar. No shoot was observed on this MS modified medium and callus turned dark brown to black following the subcultures. Previous studies reported that cytokinin alone could not induce sufficient shoot regeneration. The regeneration increased significantly when both BAP and Kinetin were used simultaneously in combination with NAA (Yadav \& Ahmad, 2013) or when BAP $2 \mathrm{mg} / \mathrm{L}$ was used in the MS medium containing IBA $0.5 \mathrm{mg} / \mathrm{L}$ (Thirunavukkarasu et al., 2015) or NAA $0.5 \mathrm{mg} / \mathrm{L}$ (Jamil et al., 2017). Therefore, the studies suggest that a combination of cytokinin and auxin is needed for in vitro regeneration of callus cultures in sugarcane.

The number of shoots and regeneration rate was also influenced by the growth regulators. The highest shoots (20 per culture) were observed in presence of Kin $2 \mathrm{mg} / \mathrm{L}$ + IAA $1 \mathrm{mg} / \mathrm{L}$. The present results are in agreement with previous reports given by other investigators who used cytokinin in combination with auxin in micropropagation of sugarcane cultivars (Suhesti et al., 2016); (Jamil et al., 2017); (Alcantara et al., 2014; Kay Thi, Htwe, \& San, 2018). ence, a high ratio of cytokinin to auxin in the regeneration medium was essential for the differentiation of adventitious shoot in sugarcane leaf folded callus.

Experiments on the induction of callus and regeneration of shoot from callus tissue concluded that a high ratio of auxin in combination promoted callus formation and induction of embryo, on the other hand, high level of cytokinin in combination stimulated plant regeneratio (Jagadeesh, Kumar, Shekhar, Sudhakar, \& others, 2011); (Thirunavukkarasu et al., 2015); (Jamil et al., 2017).

\section{CONCLUSION}

It is concluded that $2.5 \mathrm{mg} / \mathrm{L} 2,4 \mathrm{D}$ is more effective to induce callus formation than other concentration. Morphogenic dry nodular and friable callus formed from leaf sheat explants on MS medium containing different concentrations of 2,4- 
D. A combination of cytokinin and auxin is essential for shoot regeneration in sugarcane callus culture. To obtain regenerative callus from leaf sheat explants of sugarcane, 2,4 D at a concentration of less than $5 \mathrm{mg} / \mathrm{L}$ is recommended to use and a high ratio of cytokinin to auxin is necessary for plantlets regeneration.

\section{REFERENCES}

Alcantara, G. B. de, Dibax, R., Oliveira, R. 的 A. de, Bespalhok Filho, J. C., \& Daros, E. (2014). Plant regeneration and histological study of the somatic embryogenesis of sugarcane (Saccharum spp.) cultivars RB855156 and RB72454. Acta Scientiarum. Agronomy, 36(1), 63-72.

Balagalla, D. N., Wijesuriya, A., 皘 Ranathunge, N. P., \& Perera, A. (2017). A protocol for in-vitro direct plant regeneration from leaf tissues for micropropagation of sugarcane.

Biradar, S., Biradar, D. P., Patil, V. C., 程 Patil, S. S., \& Kambar, N. S. (2010). In vitro plant regeneration using shoot tip culture in commercial cultivar of sugarcane. Karnataka Journal of Agricultural Sciences, 22(1).

de Souza, A. P., Grandis, A., Leite, D. C. 豇 C., \& Buckeridge, M. S. (2014). Sugarcane as a bioenergy source: history, performance, and perspectives for second-generation bioethanol. BioEnergy Research, 7(1), 24-35.

Dewi, A. M., Manuhara, Y. S. W., 豇 Winarsih, S., \& Purnobasuki, H. (2017). Growth and development of plant tissue culture and conventional seed source from several varieties sugar cane (Saccharum officinarum L.) on field. BIOSCIENCE RESEARCH, 14(2), 323-330.
Getnet, B. (2017). Review on in vitro

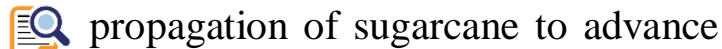
the value of tissue culture. Agri Res Tech: Open Access J, 5(4), 555670.

Hailu, M., Chimdessa, M., \& Muthswamy, EQ M. (2018). In Vitro Propagation of Selected Sugarcane (Saccharum Officinarum L.) Varieties (C 86-165 and $C$ 86-12) Through Shoot Apical Meristem. Hort Agric, 3(1), 1-7.

Jagadeesh, B., Kumar, M. H., Shekhar, M. 玨 R., Sudhakar, P., \& others. (2011). Amenability of the sugarcane variety $2005 \mathrm{~T} 16$ to shoot tip culture. Journal of Sugarcane Research, 1(2), 75-77.

Jamil, S., Shahzad, R., Talha, G. M., EQ Sakhawat, G., Sultana, R., Iqbal, M. Z., \& others. (2017). Optimization of protocols for in vitro regeneration of sugarcane (Saccharum officinarum). International Journal of Agronomy, 2017.

Kay Thi, O. O., Htwe, M. M., \& San, N. N. EQ (2018). In vitro Regeneration of Sugarcane (Saccharum officinarum) Varieties GUI 11 and PMA 96/48. Journal of Scientific and Innovative Research, 7(1), 7-11.

Kona, P., Kumar, M. H., Reddy, K. H. P., Reddy, D. M., Reddy, N. P. E., Latha, P., \& Balaji, M. S. (2019). Effect of 2, $4 D$ and EMS On in vitro Regeneration in Sugarcane Cultivar, Co86032.

Rao, A. S. (2015). Callus induction and Organogenesis in Sugarcane (Saccharum officinarum L.) var 93v297. International Letters of Natural Sciences, 48.

Redae, M. H., \& Ambaye, T. G. (2018). In 铲 Vitro propagation of sugarcane 
(Saccharum officinarum L.) variety C86-165 through apical meristem. Biocatalysis and Agricultural Biotechnology, 14, 228-234.

Sholeha, W., Sugiharto, B., Setyati, D., \& 县 Dewanti, P. (2015). Induction somatic embryogenesis used 2, 4dichlorophenoxyacetic acid (2, 4-D) and kinetin in spindle leaf explant sugarcane. Jurnal ILMU DASAR, 16(1), 17-22.

Silveira, V., de Vita, A. M., Macedo, A. F., 国 Dias, M. F. R., Floh, E. I. S., \& SantaCatarina, C. (2013). Morphological and polyamine content changes in embryogenic and non-embryogenic callus of sugarcane. Plant Cell, Tissue and Organ Culture (PCTOC), 114(3), 351-364.

SUHESTI, S. R. I., KHUMAIDA, N., 的 HUSNI, A. L. I., Genetik, B. B. S., Pertanian, B., HADIPOENTYANTI, E., ... others. (2016). Induksi Kalus dan Regenerasi Dua Varietas Tebu (Saccharum Officinarum L.) secara In Vitro.
Tesfa, M., \& Ftwi, M. (2018). Journal of 畺 Plant Biochemistry \& Physiology.

Thirunavukkarasu, D. P., Saraniya, A. R., EQ \& Ramanathan, T. (2015). In vitro studies of sugarcane variety co91017 through micropopagation of shoot tip culture. Adv Plants Agric Res, 2(6), 234-238.

Tiwari, S., Arya, A., \& Kumar, S. (2012). EQ Standardizing sterilization protocol and establishment of callus culture of sugarcane for enhanced plant regeneration in vitro. Research Journal of Botany, 7(1), 1.

Wardani, A. K., \& Pertiwi, F. N. E. (2013). EQ Produksi etanol dari tetes tebu oleh Saccharomyces Cerevisiae pembentuk flok (Nrrl--Y 265). Agritech, 33(2).

Yadav, S., \& Ahmad, A. (2013). EQ Standardisation of callus culture techniques for efficient sugarcane micropropagation. Cibtech J. BioProtoc, 2(2), 29-32. 